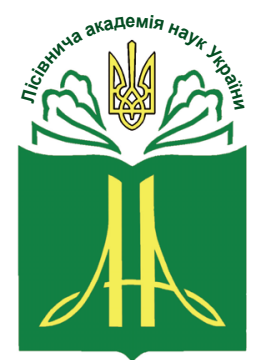

Forestry Academy of Sciences of Ukraine

Наукові праці Лісівничої академії наук України Proceedings of the Forestry Academy of Sciences of Ukraine

http://fasu.nltu.edu.ua https://doi.org/10.15421/412117

Article received 2020.11.18

Article accepted 2021.06.10
ISSN 1991-606X print

ISSN 2616-5015 online

(a) $\triangle$ Correspondence author

Iryna Koval

Koval_Iryna@ukr.net

Pushkinska str., 86, Kharkiv, 61024, Ukraine

УДК 630.561 .24

\title{
Кліматичний сигнал у регіональній деревно-кільцевій хронологіï Pinus sylvestris L. у Лівобережному Лісостепу
}

\author{
І. М. Коваль ${ }^{1}$
}

Знання щзодо реакиії деревостанів на минулі умови довкілля можуть допомогти передбачити, як ліси можуть реагувати на майбутній клімат. Вплив клімату на радіальний приріст Pinus sylvestris L. y cocняках Лiвобережного Лісостепу досліджено в умовах свіжсго бору та свіжого субору із застосуванням стандартних дендрохронологічних методик. Створено регіональну деревно-кільцеву хронологію сосни звичайної, яка складається з 80 індивідуальних деревно-кільцевих серій $і$ базується на шести локальних деревно-кільиевих хронологіях, які містять 5424 шари річної деревини. На основі иієї серї побудовано індексну серію RESIDUAL, з якої вилучено віковий тренд, щзо зробило ї̈ придатною для подальшого поглибленого дендрокліматичного аналізу. Виявлено реперні роки мінімального приросту (1936, 1942, 1954, 1975, 1979, 2000, 2005, 2009 та 2012), упродовж яких ширина шарів річної деревини була меншою, порівняно з відповідними значеннями попереднього року, на 20-46\%. Радіальний приріст упродовж изих років обмежували опади, високі температури вегетаційного періоду, екстремальні зимові та ранньовесняні температури. Роки максимального приросту (1935, 1943, 1953, 1988, 2004, 2011 та 2014) характеризувалися сприятливим співвідношенням тепла і вологи. До 1979 р. упродовж мінімальних реперних років радіальний приріст обмежували, насамперед, низькі температури $і$ посухи, але після 1979 р. - лише посухи і теплі зими. За допомогою програми RESPONSE з використанням кореляційного та регресійного аналізів між радіальним приростом сосни та кліматичними чинниками виявлено, щуо впродовж другого періоду (1989-2017 рр.), порівняно з першим (1960-1988 рр.), посилився негативний вплив температур та позитивний вплив опадів упродовж квітня-серпня на радіальний приріст. У першому періоді позитивний вплив опадів упродовж вегетаційного періоду тривав мениий термін - тільки червень-липень. У другому періоді температури червня-грудня попереднього року сильніше впливали на радіальний приріст поточного року на відміну від опадів, вплив яких навпаки - зменшився. Отже, сосна стала чутливішою до впливу клімату впродовж 1989-2017 рр. порівняно з 1960-1988 рр. Це проявилося у збільшенні значущих зв'язків між радіальним приростом сосни та кліматичними чинниками у другому періоді порівняно з першим, щзо свідчить про ослаблення насаджень і про можливе деяке погіршення радіального приросту найближчими роками. Однак, зважаючи на пластичність сосни та ї̈ адаптацію до змін клімату на нинішньому етапі, можемо рекомендувати ї̈ подальше використання в сосняках Лівобережного Лісостепу.

Ключові слова: зміна клімату; радіальний приріст сосни звичайної; реперні роки; чутливість дерев; програма RESPONSE; корелячійний та регресійний аналізи.

Коваль Ірина Михайлівна - член-кореспондент Лісівничої академії наук України, кандидат сільськогосподарських наук, старший науковий співробітник, провідний науковий співробітник лабораторії екології лісу. Український науково-дослідний інститут лісового господарства та агролісомеліорації ім. Г. М. Висоцького, вул. Пушкінська, 86, м. Харків, 61024, Україна. Тел.: +38-063-28-21-995. E-mail: Koval_Iryna@ukr.net ORCID https://orcid.org/0000-0001-6328-1418 
Вступ. Зміна клімату суттєво впливає на збереження, продуктивність та управління лісовими екосистемами у всьому світі (Allen et al., 2010; Natalini, Correia, Javier, Vázquez, \& Reyes, 2015; Gleason et al., 2018). Середньорічна температура на різних континентах підвищилася щонайменше на $1-3^{\circ} \mathrm{C}$, при цьому опади одночасно зменшилися (Dai, 2010). Оскільки інтенсивність посух і температур продовжують зростати, очікується, що ліси можуть стати дедалі вразливішими до всихання, пов'язаного зі зміною клімату (Didukh, 2009; Clark et al., 2016; Nolan et al., 2018). Тривала посуха ослаблює деревостани, що призводить до пошкодження їх шкідниками, а також до підвищеного ризику виникнення пожеж (Meshkova \& Bajdyk, 2017).

Практичні підходи до сталого управління лісами, що враховують потенційний клімат у майбутньому, розглянуто у багатьох дослідженнях (Nolan et al., 2018). Щоб зрозуміти реакцію лісів на зміну клімату потрібно оцінити їхню вразливість та розробити заходи, які можуть обмежити вплив майбутніх кліматичних змін (Natalini et al., 2015). Знання щодо реакції лісостанів на минулі умови можуть допомогти передбачити, як ліси можуть реагувати на майбутній клімат. Глобальне потепління змінює умови життя дерев, і якщо їм не вдасться адаптуватися до темпу цих змін, то межі їхнього ареалу можуть зміститися найближчими десятиліттями (Cedro, 2016; Finley \& Zhang, 2019). Цікаві у цьому контексті соснові деревостани Лівобережного Лісостепу України, які посідають друге місце за площею (190 тис. га) серед насаджень інших деревних порід.

Одним із найперспективніших напрямів досліджень в екології є дендрокліматологія, яка виявляє екологічні чинники, що впливають на продуктивність деревостанів, дає змогу здійснюва- ти біоіндикацію і прогнозувати стан лісових екосистем, що має важливе значення для моніторингу лісів (Cook \& Kairiukstis, 1990). Дендрохронологія $є$ важливим інструментом оцінювання довготривалої реакції лісів на умови довкілля, оскільки ряди деревних кілець забезпечують точніше вирішення проблем лісових екосистем, ніж лише дані довгострокової інвентаризації. Дендрохронологічні дослідження використовують підвищення чутливості шарів деревини до впливу клімату як ознаку підвищеного ризику смертності (McDowell et al., 2008). Багато дослідників використовувало деревно-кільцеві хронології для вивчення реакції росту дерев на довгострокові наслідки клімату (Adams \& Kolb 2005; Koval, 2013; Olivar, Rathgeber \& Bravot, 2015; Natalini1 et al., 2015; Gritsan, Lovynska, Sytnyk, \& Hetmanchuk, 2019).

За умов потепління клімату надзвичайно важливими є дослідження адаптації лісових екосистем до зміни клімату. Ці актуальні питання допоможуть вирішити дендрокліматичні дослідження.

Об' скти та методика дослідження. Об 'єктами дослідження є соснові насадження віком від 59 до 100 років, які ростуть в умовах свіжого бору $\left(A_{2}\right)$ та свіжого субору $\left(B_{2}\right)$ на дернових слабопідзолистих супіщаних грунтах. Предметом дослідження є динаміка радіального приросту Pinus sylvestris L. під впливом кліматичних чинників. Meта дослідження - виявити основні кліматичні чинники, які впливають на радіальний приріст сосни звичайної у деревостанах Лівобережного Степу в умовах змін клімату.

Дослідження здійснено на шести пробних площах (ПП) у соснових насадженнях, з яких одне насадження росте в умовах $A_{2}$, а п'ять - в умовах $B_{2}$ (табл. 1).

Характеристика досліджуваних соснових насаджень у Лісостепу

Таблиия 1

\begin{tabular}{|c|c|c|c|c|c|c|c|c|c|c|}
\hline $\begin{array}{l}\text { № } \\
\text { ПП }\end{array}$ & $\begin{array}{l}\text { Географічні } \\
\text { координати }\end{array}$ & $\begin{array}{c}\text { Висота } \\
\text { над рівнем } \\
\text { моря, м }\end{array}$ & $\begin{array}{l}\text { Індекс } \\
\text { ТЛУ }\end{array}$ & Склад & $\begin{array}{l}\text { Вік, } \\
\text { років }\end{array}$ & Повнота & $\mathrm{D}, \mathrm{cm}$ & $\mathrm{H}, \mathrm{m}$ & Бонітет & $\begin{array}{l}\text { Запас, } \\
\mathrm{m}^{3} \cdot \mathrm{ra}^{-1}\end{array}$ \\
\hline 1 & $\begin{array}{l}49^{\circ} 58^{\prime} 48^{\prime \prime} \text { пн.ш. } \\
36^{\circ} 15^{\prime} 36^{\prime \prime} \text { сх.д. }\end{array}$ & 111 & $\mathrm{~A}_{2}$ & $10 \mathrm{C} 3$ & 59 & 0,75 & 24 & 20 & I & 328 \\
\hline 2 & $\begin{array}{l}49^{\circ} 27^{\prime} 45^{\prime \prime} \text { пн.ш. } \\
36^{\circ} 51^{\prime} 34^{\prime \prime} \text { сх.д. }\end{array}$ & 80 & $\mathrm{~B}_{2}$ & $10 \mathrm{C} 3$ & 85 & 0,80 & 23 & 22 & I & 404 \\
\hline 3 & $\begin{array}{l}49^{\circ} 27^{\prime} 45^{\prime \prime} \text { пн.ш. } \\
36^{\circ} 51^{\prime} 34^{\prime \prime} \text { сх.д. }\end{array}$ & 80 & $\mathrm{~B}_{2}$ & $10 \mathrm{C} 3$ & 90 & 0,80 & 22 & 21 & I & 404 \\
\hline 4 & 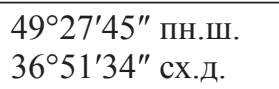 & 80 & $\mathrm{~B}_{2}$ & $10 \mathrm{C} 3$ & 90 & 0,76 & 25 & 21 & I & 406 \\
\hline 5 & $\begin{array}{l}\text { 49॰49'36" пн.ш. } \\
36^{\circ} 19^{\prime} 38^{\prime \prime} \text { сх.д. }\end{array}$ & 109 & $\mathrm{~B}_{2}$ & $10 \mathrm{C} 3$ & 74 & 0,82 & 38 & 23 & I & 435 \\
\hline 6 & $\begin{array}{l}50^{\circ} 02^{\prime} 45^{\prime \prime} \text { пн.ш. } \\
36^{\circ} 19^{\prime} 42^{\prime \prime} \text { сх.д. }\end{array}$ & 109 & $\mathrm{~B}_{2}$ & $10 \mathrm{C} 3$ & 100 & 0,60 & 42 & 24 & II & 310 \\
\hline
\end{tabular}

Примітки. ПП - пробні площі; 1 - ДП «Жовтневе ЛГ» Бабаївське лісництво, 32 кв., 5 вид.; 2 - ДП «Балаклійське ЛГ» Високобірське лісництво, кв. 66, вид. 65; 3 - ДП «Балаклійське ЛГ» Високобірське лісництво, кв. 65, вид. 4; 4 - ДП «Балаклійське ЛГ» Високобірське лісництво, кв. 61, вид.; 5 - ДП «Балаклійське ЛГ» Савинське лісництво, кв.52; 6 - ДП «Жовтневе ЛГ» Васищівське лісництво, кв. 104, вид. 4; 14 - ДП «Харківська науково-дослідна станція» (Данилівський лісгосп Південне лісництво), кв. 159, вид. 7 
Використано таксаційні, дендохронологічні та статистичні методи (Cook \& Kairiukstis, 1990). Kepни відібрано буравом Преслера у 15-20 дерев сосни звичайної в біогрупі дерев на висоті 1,3 м від комля. Шари річної деревини виміряно цифровим приладом HENSON 3 точністю до 0,01 мм. Перехресним датуванням встановлено точну календарну дату кожного шару деревини; пізніше якість вибірки перевірено програмою COFЕСНА. Сегменти кернів з низькими значеннями кореляції та керни, які не підлягали датуванню, було вилучено з вибірки (Cook \& Kairiukstis 1990; Holmes, 1994).

Для вивчення загальних тенденцій зміни радіального приросту дерев у часі, виявлення екстремумів приросту, зв'язків індексів радіального приросту з метеорологічними умовами, застосовано методи порівняльного і внутрішньорядного аналізу. До вивчення екстремальних значень радіального приросту застосовано поняття реперних років (Génova, 2012). Реперні роки були визначено з урахуванням того, що значення або індекси приросту передбачають зменшення чи збільшення більш ніж на 20\% показника приросту поточного року порівняно 3 попереднім. Позитивні та негативні екстремуми приросту для реперних років присутні як мінімум у 75\% індивідуальних деревно-кільцевих серій (Andreu, Planells, Gutiérrez, Helle \& Schleser, 2008; Elferts, 2007). Для аналізу взаємозв'язків між кліматом і радіальним приростом використано поняття «норма», що визначає усереднені значення температури повітря та опадів за період 1960-2017 роки. Відхилення від норми чинників опадів і температур для років із екстремальними кліматичними явищами (посухами, холодними зимами тощо) виражено у відсотках (Коваль, Воронін, 2019).

Стандартне відхилення вимірює мінливість річних кілець. Середня чутливість $€$ мірою середньої відносної зміни між сусідніми ширинами кільця, яку вираховували як абсолютну різницю між сусідніми індексами, поділену на середнє значення цих індексів. Автокореляція першого порядку оцінює взаємозв'язки з попереднім приростом. Вища загальна дисперсія, яка припадає на перший основний компонент, вказує на більший кліматичний вплив на ріст дерев (Fritts, 1976; Cook \& Kairiukstis 1990). Обчислено міжсерійний коефіцієнт кореляції $\left(R_{b a r}\right)$, який визначено як середню кореляцію між усіма деревно- кільцевими хронологіями (Wigley, 1984). Популяційний сигнал (EPS) обчислено для оцінення внутрішньої сили сигналу хронології i виражає надійність вимірювань у хронології та $€$ функцією коефіцієнта $R_{b a r}$ :

$$
\operatorname{EPS}(t)=\frac{t R_{b a r}}{t R_{b a r}+\left(1-R_{b a r}\right)}
$$

де $t$ - кількість деревно-кільцевих серій, $R_{b a r}-$ середня кореляція між деревно-кільцевими хронологіями.

Про придатність деревно-кільцевої серії для подальшого дендрокліматичного аналізу свідчить перевищення порогу EPS вище 0,85 (Wigley, 1984).
Методом стандартизації, тобто створенням деревно-кільцевих індексних хронологій за допомогою програми ARSTAN, вилучено вікові тренди з індивідуальних деревно-кільцевих серій, що дало змогу порівняти дерева 3 насаджень різного віку та знайти відгук радіального приросту на вплив кліматичних умов. Ця процедура $є$ фільтрацією низькочастотної складової у багаторічних коливаннях приросту (Cook \& Kairiukstis 1990; Cook \& Peters, 1997).

На першому етапі вилучення трендів використано від'ємну експоненціальну криву, а на другому - кубічну ковзну криву. Індекси радіального приросту сформовано способом ділення реального значення ширини річного кільця на його прогнозоване значення. Внаслідок цього створено ряди індексів радіального приросту із середнім значенням 1 та однорідною дисперсією. У дендрокліматичних дослідженнях часто використовують хронології RESIDUAL, в яких видалено також автокореляцію для посилення кліматичного сигналу внаслідок вилучення вікового тренду (Cook \& Kairiukstis, 1990). Середне значення локальних і регіональної хронологій обчислено із застосуванням середньозваженого (Wigley, Briffa \& Jones, 1984).

Для встановлення зв'язків між чинниками клімату і радіальним приростом сосни використано програму RESPO з пакету програм DPL, за допомогою якої здійснено аналіз відгуку та кореляційний аналіз між деревно-кільцевими хронологіями RESIDUAL і кліматичними чинниками (температурою повітря та опадами) (Marquardt et al., 2019; Holmes, 1994).

Аналіз функції відгуку - це форма множинної регресії. Здійснено багатофакторний регресійний аналіз, в якому середня місячна температура повітря та місячна сума опадів $\epsilon$ незалежними змінними. Застосовано покроковий регресійний аналіз для відбору найвпливовіших на радіальний приріст кліматичних чинників, а також метод головних компонент - для вилучення кліматичних чинників із аналізу, які тісно корелюють між собою та множинний регресійний аналіз - для оцінювання впливу клімату на приріст. Аналіз функції відгуку застосовували для відстеження впливу кліматичних чинників на радіальний приріст за 15 -місячний період (з червня попереднього року по серпень поточного року) (Holmes, 1994). Для відбору кращих змінних для цієї регресійної моделі використано кореляційний аналіз між індексними деревно-кільцевими хронологіями сосни і середньомісячними температурами повітря $\left({ }^{\circ} \mathrm{C}\right)$ та сумами опадів (мм).

Для дендрокліматичного аналізу використано дані Харківської метеостанції. Клімат помірно континентальний. Найтеплішим $\left(21,2^{\circ} \mathrm{C}\right)$ і найвологішим (68 мм) місяцем є липень, а найхолоднішим - січень $\left(-5,4^{\circ} \mathrm{C}\right)$; найменша кількість опадів характерна для березня (34 мм). Середня річна температура становить $8,1^{\circ} \mathrm{C}$, а сума опадів - 552 мм (рис. 1). 


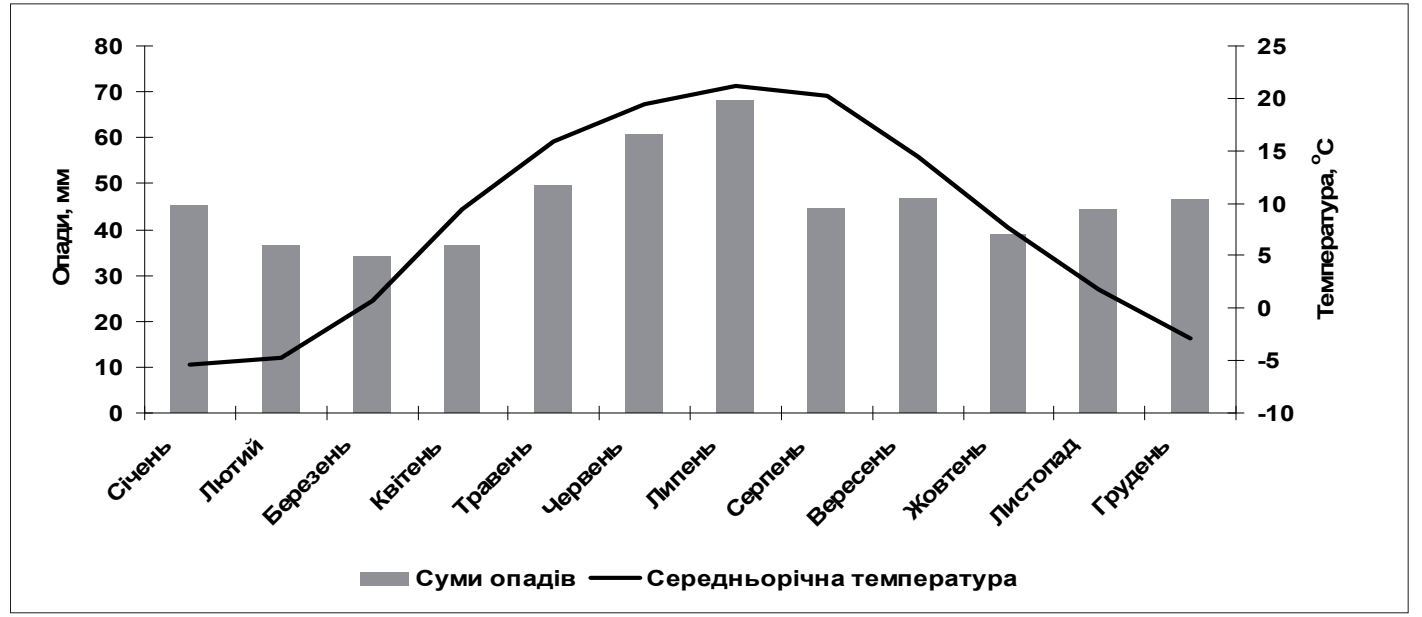

Рис. 1. Кліматограма Харківської метеорологічної станції

(географічні координати 4955'28" пн. ш. 36²17'24" сх. д., висота над рівнем моря 155 м) для 1960-2018 рр.

Результати та обговорення. Створена регіональна деревно-кільцева хронологія Pinus sylvestris L. для Лісостепу складається 380 індивідуальних деревно-кільцевих серій і базується на шести локальних деревно-кільцевих хронологіях, які містять 5424 шари річної деревини (рис. 2). На основі цієї серії побудовано індексну серію RESIDUAL, з якої вилучено віковий тренд, що зробило іiї придатною для подальшого поглибленого дендрокліматичного аналізу (рис. 3). Міжсерійні коефіцієнти кореляції коливаються в межах 0,318-0,472, що свідчить про високу синхронність та можливість використання цих деревно-кільцевих хронологій для подальшого дендрокліматичного аналізу (табл. 2). Високі значення автокореляції першо- го порядку $(0,524-0,804)$ свідчать про високу залежність величини річного кільця поточного року від річного кільця попереднього року. Насадження, яке росте в умовах $A_{2}$, має меншу залежність від умов попередніх років, ніж насадження, які ростуть в умовах $B_{2}$, що можна пояснити менш сприятливими умовами зростання у свіжому бору порівняно із свіжим субором, де грунти трохи багатші і мають більшу вологоємкість. Найстійкішими до впливу чинників довкілля виявилися насадження, що ростуть в умовах $B_{2}$ (ПП 2-6), і найменш стійким - деревостан, що росте в умовах $A_{2}$ (ПП 1). Про це свідчать стандартне відхилення та середня чутливість, значення яких $є$ найменшими для ПП 2-6 і найбільшими - для ПП 1 (див. табл. 1, 2).

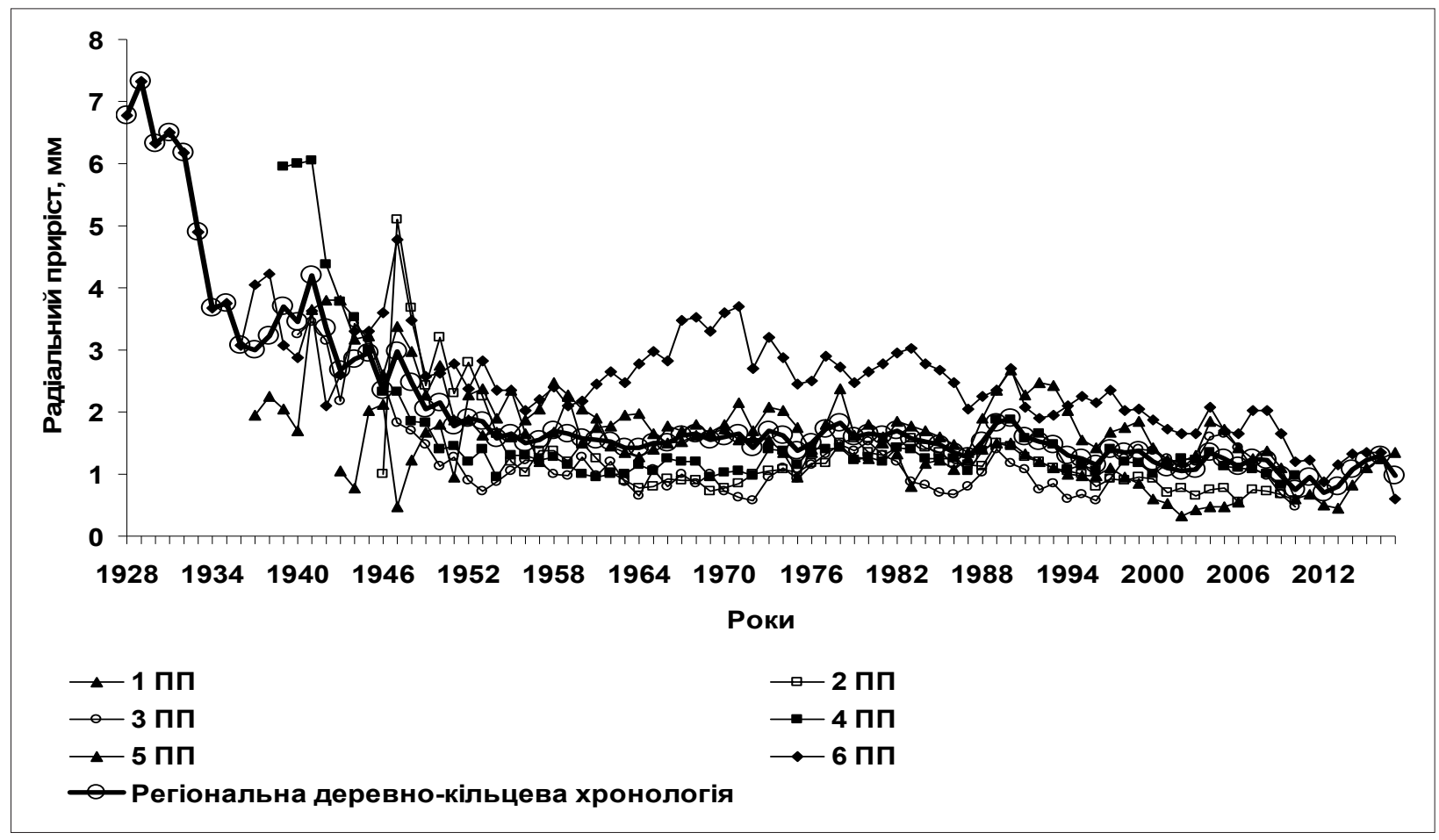

Рис. 2. Динаміка локальних та регіональної деревно-кільцевих хронологій Pinus sylvestris L. у насадженнях Лівобережного Лісостепу 


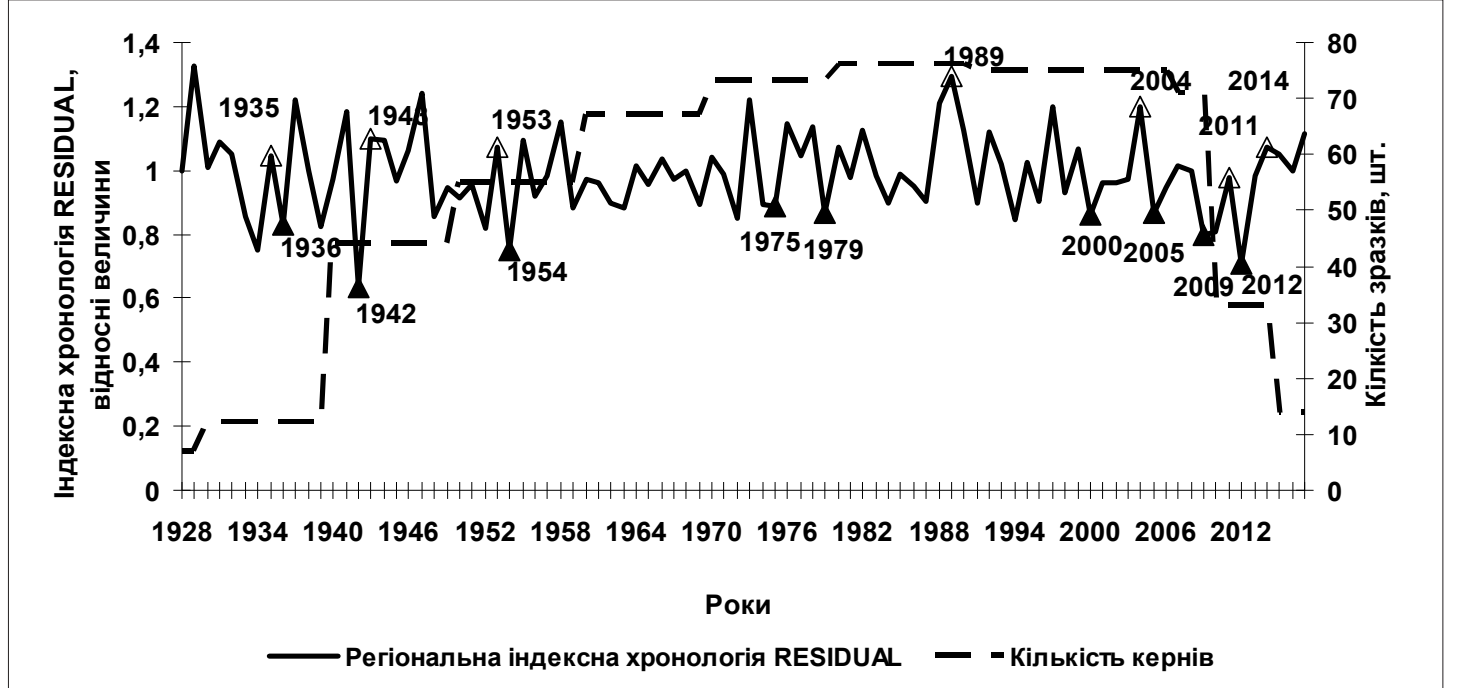

Рис. 3. Динаміка регіональної індексної деревно-кільцевої хронології RESIDUAL та кількість кернів (чорні трикутники - негативні реперні роки, білі трикутники - позитивні реперні роки)

Табличя 2

\section{Статистична характеристика локальних і регіональної серій деревно-кільцевих хронологій} Pinus sylvestris L. у Лісостепу за програмами COFECHA ta ARSTAN

\begin{tabular}{|c|c|c|c|c|c|c|c|c|c|}
\hline \multirow{2}{*}{$\begin{array}{l}\text { № } \\
\text { ПП }\end{array}$} & \multirow{2}{*}{$\begin{array}{l}\text { Проміжок } \\
\text { часу, роки }\end{array}$} & \multirow{2}{*}{$\begin{array}{c}\text { Середнє } \\
\text { значення, } \\
\text { мм }\end{array}$} & \multicolumn{4}{|c|}{ Неіндексовані серії } & \multicolumn{3}{|c|}{ RESIDUAL cepiï } \\
\hline & & & $\mathrm{R}_{\text {bar. }}$ & $\mathrm{S}_{\mathrm{td} . \mathrm{dev}}$ & $\mathrm{AC}_{1}$ & $\mathrm{MS}_{\mathrm{x}}$ & Середнє & $\mathrm{MS}_{\mathrm{x}}$ & $\mathrm{S}_{\mathrm{td} d \mathrm{dev}}$ \\
\hline 1 & $1940-2006$ & 1,27 & 0,318 & 0,806 & 0,524 & 0,375 & 1,00 & 0,186 & 0,171 \\
\hline 2 & $1944-2010$ & 1,05 & 0,337 & 0,576 & 0,700 & 0,253 & 0,986 & 0,177 & 0,156 \\
\hline 3 & $1940-2010$ & 0,99 & 0,325 & 0,650 & 0,703 & 0,345 & 0,99 & 0,226 & 0,211 \\
\hline 4 & $1940-2010$ & 1,45 & 0,460 & 0,965 & 0,708 & 0,234 & 0,99 & 0,167 & 0,140 \\
\hline 5 & $1940-2017$ & 1,63 & 0,472 & 0,945 & 0,586 & 0,328 & 1,00 & 0,232 & 0,272 \\
\hline 6 & $1920-2016$ & 2,46 & 0,413 & 1,730 & 0,804 & 0,218 & 0,998 & 0,188 & 0,198 \\
\hline Р.д-к.с. & $1920-2017$ & 1,69 & 0,353 & 1,116 & 0,705 & 0,263 & 1,00 & 0,176 & 0,203 \\
\hline
\end{tabular}

Примітки. ПП - пробна площа; $\mathrm{R}_{\text {bar. }}$ - міжсерійний коефіцієнт кореляції; $\mathrm{S}_{\text {tddev }}$ стандартне відхилення; $\mathrm{AC}_{1}$ - автокореляція першого порядку; $\mathrm{MS}_{\mathrm{x}}$ - середня чутливість; $\mathrm{S}_{\mathrm{tddev}}$-стандартне відхилення; Р.д.с. - регіональна деревно-кільцева серія

Коефіцієнт EPS, обчислений для регіональної деревно-кільцевої хронології RESIDUAL, становить 0,98 , що також підтверджує можливість здійснення дендрокліматичного аналізу, оскільки перевищує поріг 0,85 і підтверджує надійність хронології, тобто є показником подібності дисперсії хронології вибірки і теоретичної хронології генеральної сукупності (Wigley et al., 1984). Коефіцієнт чутливості перевищує 0,2 , що дає змогу використовувати пропоновану деревно-кільцеву хронологію у дендрокліматичному аналізі (див. табл. 2). Використання наведених вище чинників для визначення надійності дендрохронологічних серій доказано низкою досліджень (Wigley, Briffa \& Jones, 1984; Génova, 2011).

Виявлено реперні роки мінімального приросту $(1936,1942,1954,1975,1979,2000,2005,2009$ та 2012), упродовж яких ширина шарів річної деревини була нижчою, порівняно $з$ попереднім ро- ком, на 20-46\%. Ці роки характеризувалися посухами упродовж вегетаційного періоду $(1975,1979$, 2009 рр.) та екстремальними літніми $(2000,2000$, $2012)$, зимовими та ранньовесняними $(1979,2005)$ температурами (див. рис. 3, табл. 3). Радіальний приріст упродовж мінімальних реперних років обмежували дефіцит опадів в окремі місяці вегетації $(\Delta-54-63 \%)$, високі температури упродовж вегетаційного періоду $(\Delta+9-15 \%)$, низькі зимові температури $(\Delta-38 \%)$, високі березневі температури $(\Delta+70)$.

Роки максимального приросту $(1935,1943,1953$, 1988, 2004, 2011 та 2014) характеризувалися сприятливим співвідношенням тепла і вологи. Перевищення норми опадів було вищим ніж 24-31\% у квітні-серпні (див. рис. 3, див. табл. 3).

До 1979 р. упродовж мінімальних реперних років радіальний приріст обмежували низькі температури та посухи, але після 1979 р. - лише посухи i теплі зими (див. табл. 3). Подібні результати отри- 
мав А. Витас у Литві, який виявив, що негативні реперні роки для сосни звичайної були з однаковою частотою пов'язані з низькими температурами та посухами, але вже з 1970 р. - тільки високими температурами та дефіцитом вологи (Vitas, 2004).

Дерева, які ростуть у межах однорідного за кліматичними умовами регіону, однаково реагують на зміни зовнішніх умов і мають подібні тенденції в коливаннях величин річного приросту. Більшість де- рев мають синхронні зміни величин річних кілець. Б. Губер зазначав (Cook \& Peters, 1997), що крива величин річних кілець подібна на англійський замок, до якого існує тільки один ключ, а саме - визначений час. Процес перехресного датування проходить легше, коли виявляються негативні реперні роки, упродовж яких формуються вузькі кільця, коли приріст найбільшою мірою починає лімітуватися тим чи іншим зовнішнім чинником.

Реперні роки регіональної деревно-кільцевої хронології Pinus sylvestris L. у насадженнях Лівобережного Степу та кліматичні характеристики, виражені через відхилення $(\Delta)$ від норми (довгострокового середнього)

\begin{tabular}{|c|c|c|c|c|c|}
\hline \multicolumn{3}{|c|}{ Роки мінімального приросту } & \multicolumn{3}{|c|}{ Роки максимального приросту } \\
\hline Рік & $\begin{array}{c}\text { Зниження радіального } \\
\text { приросту в поточному } \\
\text { році порівняно } 3 \\
\text { попереднім роком, \% }\end{array}$ & $\begin{array}{l}\text { Кліматичні } \\
\text { чинники }\end{array}$ & Рік & $\begin{array}{c}\text { Перевищення } \\
\text { радіального приросту } \\
\text { в поточному році } \\
\text { порівняно з попереднім } \\
\text { роком, \% }\end{array}$ & $\begin{array}{l}\text { Кліматичні } \\
\text { чинники }\end{array}$ \\
\hline 1936 & 21 & Не відомо & 1935 & 40 & Не відомо \\
\hline 1942 & 46 & Не відомо & 1943 & 46 & Не відомо \\
\hline 1954 & 30 & Не відомо & 1953 & 30 & Не відомо \\
\hline 1975 & 27 & $\begin{array}{c}\text { Дефіцит опадів упродовж } \\
\text { квітня-серпня } \Delta-158 \mathrm{мм} \\
(63 \%)\end{array}$ & 1989 & 34 & $\begin{array}{c}\text { Перевищення } \\
\text { річної суми опадів } \\
\Delta+140 \text { мм }(25 \%)\end{array}$ \\
\hline 1979 & 24 & $\begin{array}{c}\text { Посуха у червні } \Delta-59 \text { мм, } \\
\text { високі березневі } \\
\text { температури } \Delta+1,17^{\circ} \mathrm{C} \\
(65 \%), \text { низькі зимові } \\
\text { температури } \Delta-8,2{ }^{\circ} \mathrm{C} \\
(38 \%)\end{array}$ & 2004 & 23 & $\begin{array}{c}\text { Перевищення } \\
\text { річної суми опадів } \\
\Delta+172 \text { мм }(31 \%)\end{array}$ \\
\hline 2000 & 20 & $\begin{array}{c}\text { Спекотний липень } \\
\Delta+1,75^{\circ} \mathrm{C}(9 \%),\end{array}$ & 2011 & 21 & $\begin{array}{c}\text { Перевищення опадів } \\
\text { за квітень-серпень } \\
\Delta+81 \text { мм }(24 \%) \\
\end{array}$ \\
\hline 2005 & 28 & $\begin{array}{l}\text { Дефіцит опадів у березні- } \\
\text { квітні } \Delta-31 \text { мм }(44 \%), \\
\text { тепла зима } \Delta+2,2{ }^{\circ} \mathrm{C}(50 \%)\end{array}$ & 2014 & 38 & \\
\hline 2009 & 20 & $\begin{array}{l}\text { Дефіцит опадів у квітні- } \\
\text { серпні } \Delta-120 \text { мм (54\%) }\end{array}$ & & & \\
\hline 2012 & 27 & $\begin{array}{c}\text { Високі температури } \\
\text { у квітні-серпні } \\
\Delta+3,1^{\circ} \mathrm{C}(15 \%)\end{array}$ & & & \\
\hline
\end{tabular}

Американські дендрохроноги довели, що радіальному приросту Pinus ponderosa Dougl. сприяла сезонна наявність весняної вологи впродовж поточного року зростання. I навпаки - висока температура навесні та на початку літа згубно впливала на ріст деревного виду (Finley, Zhang, 2019) .

Здійснено зіставлення реакції радіального приросту регіональної деревно-кільцевої хронології Лівобережного Лісостепу до впливу кліматичних чинників у періоди 1960-1988 та 1989-2017 роки. Середньорічна температура першого періоду ста- новила $7,5^{\circ} \mathrm{C}$, другого $-8,9^{\circ} \mathrm{C}$, тобто збільшення становило $1,3^{\circ} \mathrm{C}(15 \%)$. Середньорічна сума опадів упродовж першого періоду становила 536,3 мм, упродовж другого - 555,8 мм. Отже, різниця опадів між двома періодами становила 19,5 мм або 3,5\% (рис. 4).

Упродовж другого періоду посилилась залежність радіального приросту сосни звичайної від температур. У першому періоді спостережено позитивний вплив температур упродовж червня-грудня попереднього року. Виявлено також значущі пози- 
тивні зв'язки між приростом і кліматом для вересня попереднього року, але вже у другому періоді цей вплив став негативним для цього місяця.

Аналізуючи взаємозв'язки між кліматом i paдіальним приростом упродовж холодного періоду (з листопада попереднього по березень поточного року), виявлено, що впродовж першого періоду температура значуще позитивно впливала на приріст у грудні та березні, а в другому періоді позитивні зв'язки знайдено для жовтня, листопада та лютого, а негативні - для листопада, тобто підвищення температур негативно вплинуло на приріст дерев у період їхнього переходу до зимового спокою.

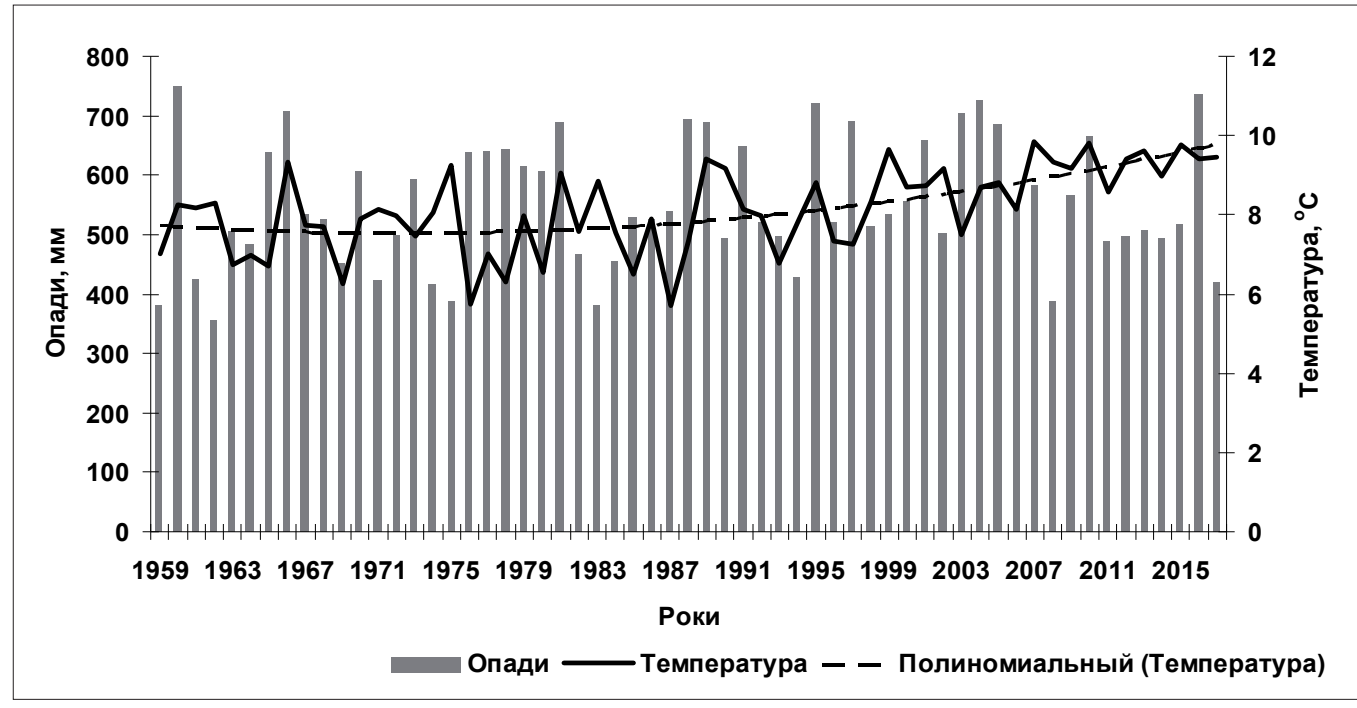

Рис. 4. Динаміка температур та опадів за даними Харківської метеостанції

Березневі температури також важливі для радіального приросту, оскільки в цей період починається процес ксилогенезу. Упродовж квітня-серпня у 1960-1989 рр. виявлено значущий позитивний вплив температур на приріст у травні, а негативний - у червні, але вже у 1990-2017 рр. негативний вплив температур посилився у квітні та серпні. Тобто у другому періоді упродовж вегетаційного сезону погіршився вплив температур на радіальний приріст сосни звичайної (рис. 5).

Аналізуючи вплив температур червня-липня попереднього року на приріст, встановлено, що більше значущих коефіцієнтів відгуку та кореляції було обчислено для другого періоду, на відміну від опа- дів, вплив яких зменшився у другому періоді за відповідний період. Виявлено значущі позитивні зв'язки для червня, липня та вересня і негативні для серпня упродовж 1960-1987 рр. та для 19602017 рр. - позитивні для червня, вересня та листопада попереднього року. Для першого періоду характерний позитивний вплив березневих опадів на приріст, на відміну від другого періоду, коли березневі опади стали обмежувати приріст. У другому періоді посилився також вплив опадів - 3 червня по травень він виявився значущим позитивним, лише у квітні він лімітував приріст на відміну від першого періоду, коли позитивний вплив опадів на приріст виявлено лише у червні та липні (рис. 6).

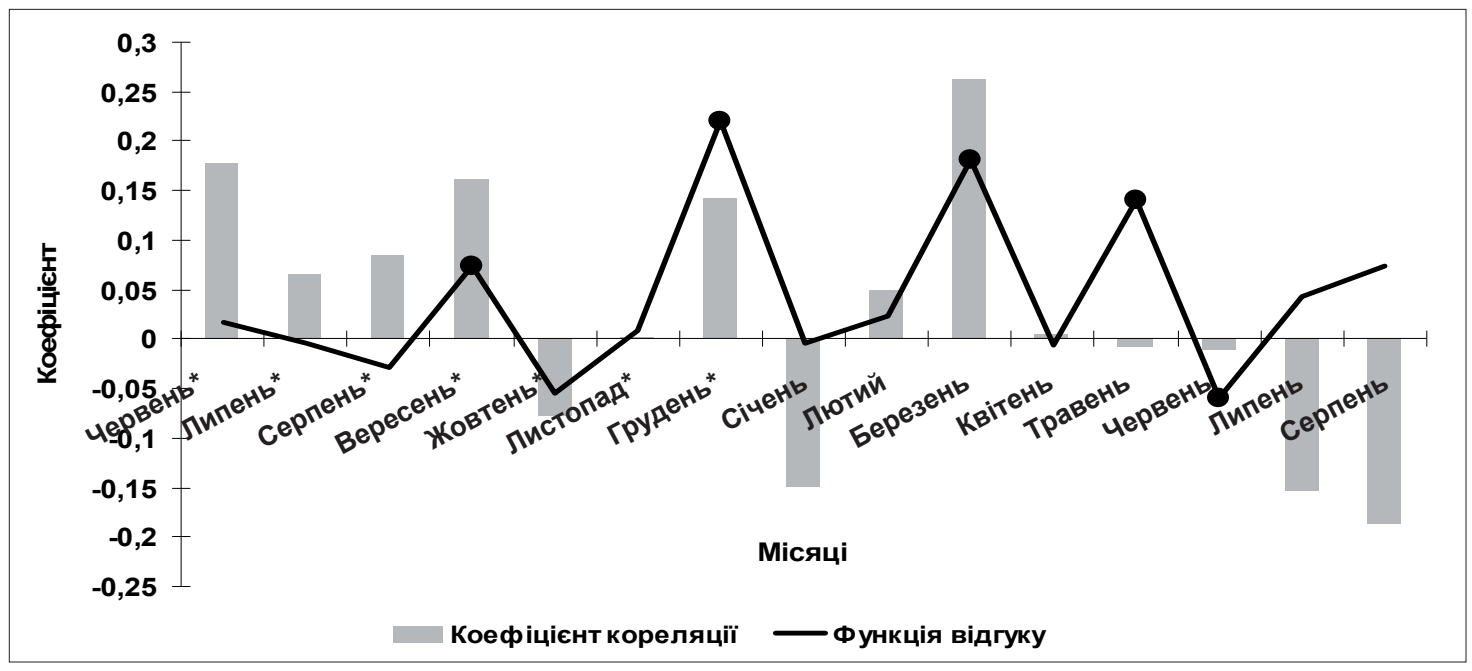

Рис. 5. А) 1960-1988 pp. 


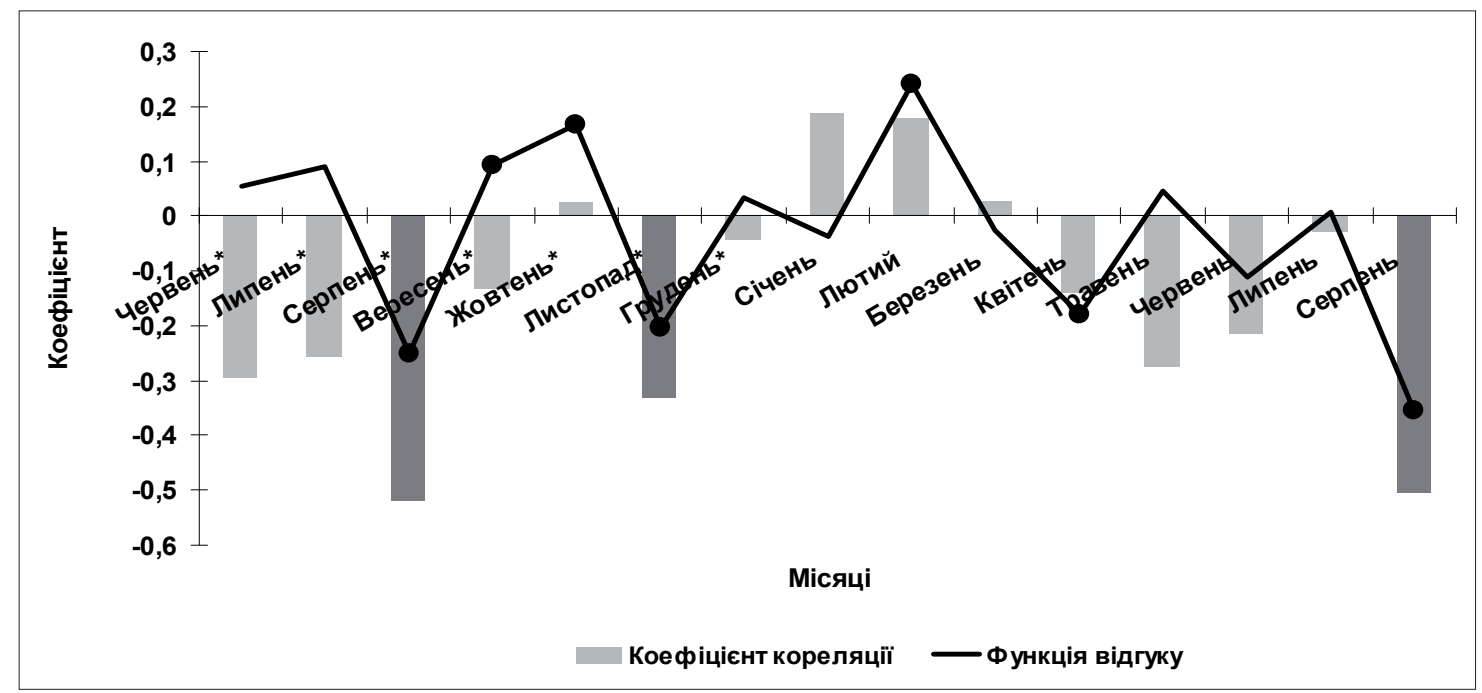

Рис. 5. Б) 1989-2017 рр. Коефіцієнти кореляції Пірсона (стовпчики) та коефіцієнти функції відгуку (лінії) між середніми місячними температурами та індексною регіональною деревно-кільцевою хронологією Pinus sylvestris L.

Лівобережного Степу (темно-сірі стовпчики вказують на значущі коефіцієнти кореляції $(\mathrm{P}<0,05)$,

чорні кола - на значущі коефіцієнти функції відгуку; зірочки (*) вказують на місяці попереднього року)

A) $1960-1987 \mathrm{pp}$.

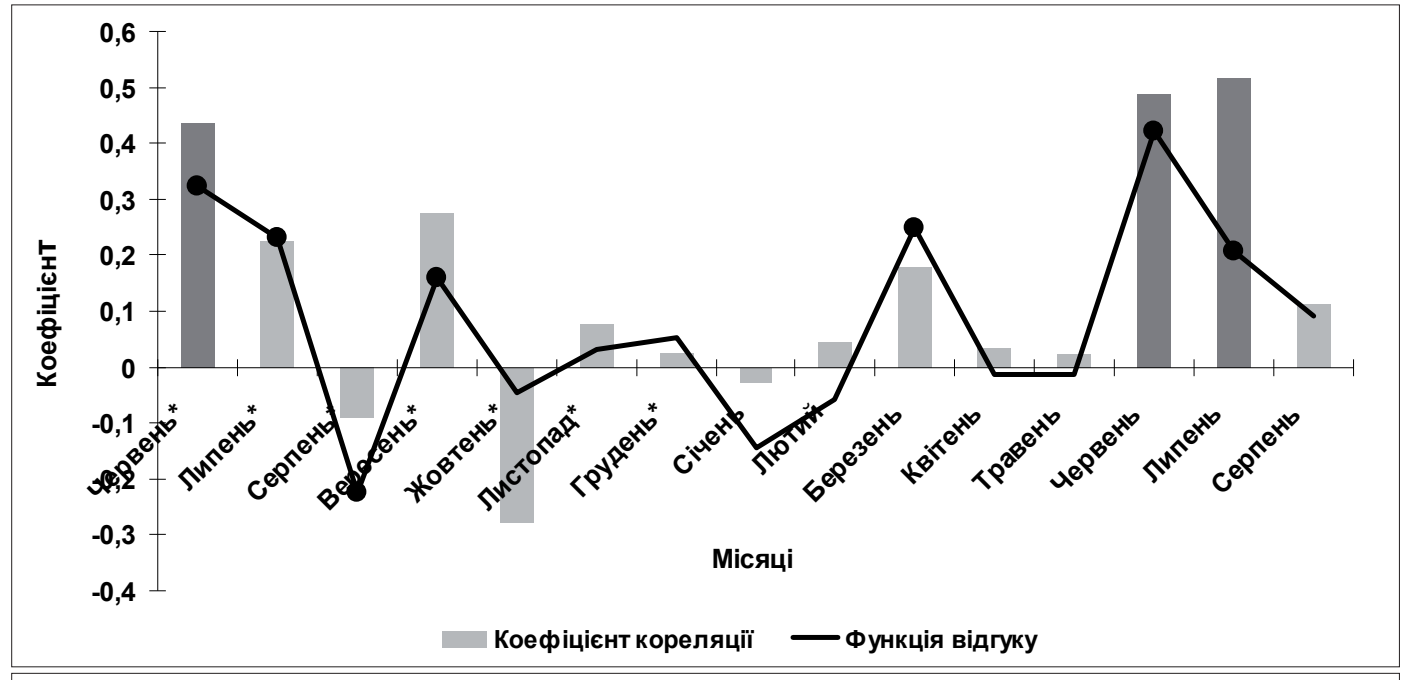

B) $1988-2017 \mathrm{pp}$.

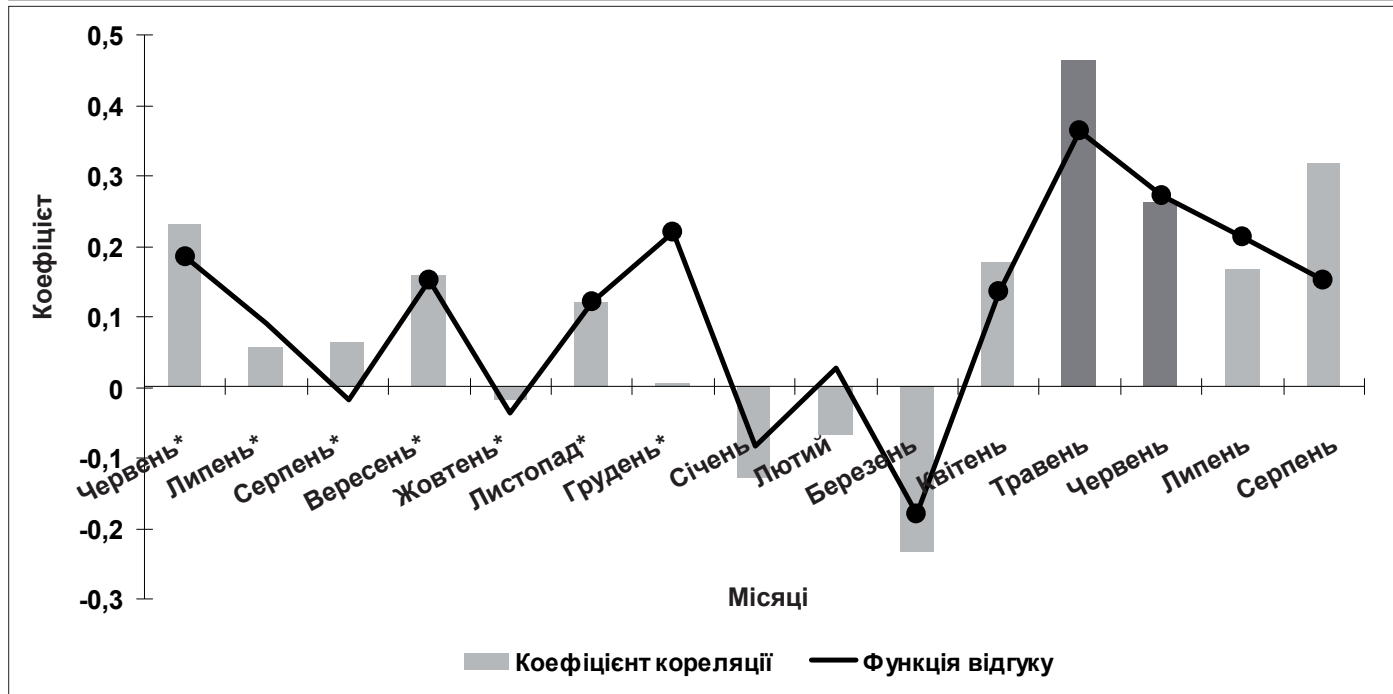

Рис. 6. Коефіцієнти кореляції Пірсона (стовпчики) та коефіцієнти функції відгуку (лінії) між кількістю опадів

та індексною регіональною деревно-кільцевою хронологією Pinus sylvestris L. Полісся (темно-сірі стовпчики вказують на значущі коефіцієнти кореляції (P < 0,05), чорні кола вказують на значущі коефіцієнти функції відгуку; зірочки (*) вказують на місяці попереднього року) 
Як і в цих дослідженнях, позитивний вплив літніх опадів на радіальний приріст сосни виявлено також у східній Феноскандії та Польщі (Linderholm, Solberg, \& Lindholm, 2003). Посилення водного стресу для Pinus nigra ssp. Pallasiana, зумовленого потеплінням клімату, визначено у Криму (Koval, 2013).

Висновки. Створена для Лісостепу регіональна деревно-кільцева хронологія сосни звичайної придатна для подальшого дендрокліматичного аналізу, бо має високі значення міжсерійного коефіцієнта кореляції та коефіцієнта EPS, який перевищує поріг 0,85 та середньої чутливості. Виявлено реперні роки мінімального приросту $(1936,1942,1954$, 1975, 1979, 2000, 2005, 2009 та 2012), упродовж яких ширина шарів річної деревини була меншою порівняно $з$ попереднім роком, на 20-46\%. Ці роки характеризувалися посухами упродовж вегетаційного періоду та екстремальними літніми, зимовими і ранньовесняними температурами. Роки максимального приросту (1935, 1943, 1953, 1988, 2004, 2011 та 2014) характеризувалися сприятливим співвідношенням тепла та вологи.

Під час порівняння реакції радіального приросту сосни звичайної на варіації клімату упродовж часових періодів 1960-1988 та 1989-2017 рр. виявлено збільшення чутливості сосни до варіацій клімату. Це проявилося у збільшенні значущих зв’язків між радіальним приростом сосни та кліматичними чинниками у другому періоді порівняно 3 першим, що свідчить про ослаблення деревостанів і про можливе деяке погіршення радіального приросту у найближчі роки. Однак зважаючи на пластичність сосни та їі адаптацію до змін клімату на нинішньому етапі, можемо рекомендувати їі використання в насадженнях Лівобережного Лісостепу.

\section{Список літератури}

Коваль І. М., Воронін В. О. (2019). Реакція радіального приросту Pinus sylvestris L. на зміну клімату в насадженнях Лівобережного Лісостепу. Лісівниuттво і агролісомеліорація, 135, 140-148. [Koval, I., \& Voronin, V. (2019). Response of Pinus sylvestris L. radial growth to climate change in stands on Left-bank. Forestry and Forest Melioration, 135, 140-148. https://doi. org/10.33220/1026-3365.135.2019.140] (in Ukrainian)

Adams, H.D., \& Kolb, T.E. (2005). Tree growth response to drought and temperature in a mountain landscape in northern Arizona, USA. Journal Biogeography, 32, 1629-1640. Retrieved from https:// onlinelibrary.wiley.com/doi/abs/10.1111/j.13652699.2005.01292.x

Allen, C. D., Macalady, A. K., Chenchouni, H., Bachelet D., Mcdowell, N., Vennetier, M. ... Cobb, N. (2010). A global overview of drought and heat-induced tree mortality reveals emerging climate change risks for forests. Forest Ecology and Management, Elsevier, 259(4), 660-684. Retrieved from https://hal. archives-ouvertes.fr/hal-00457602/document

Andreu, L., Planells, O., Gutiérrez, E, Helle G. \& Schleser, G. (2008). Climatic significance of tree- ring width and $\delta 13 \mathrm{C}$ in a Spanish pine forest network. Tellus B: Chemical and Physical Meteorology, 60(5), 771-781. Retrieved from https://onlinelibrary. wiley.com/doi/10.1111/j.1600-0889.2008.00370.x

Cedro, A. (2016). The influence of climatic conditions on the tree-ring width of wild service trees (Sorbus torminalis L.) in Wielkopolska Forest. Research Papers Czerwiec, 77(2), 117-123. Retrieved from https://depot.ceon.pl/bitstream/handle/123456 789/10841/DOI-10.1515-frp-2016-0013\%20en. pdf? sequence $=1 \&$ is Allowed $=\mathrm{y}$

Clark, J.S.; Iverson, L.; Woodall, C. W., Allen, C. D., Bell, D. M., Bragg, D.C., \& Zimmermann, E. (2016). The impacts of increasing drought on forest dynamics, structure, and biodiversity in the United States. Global Change Biology, 22, 2329-2352. Retrieved from https://www.fs.fed.us/nrs/pubs/jrnl/2016/nrs 2016 clark-j 001.pdf

Cook, E., \& Peters K. (1997). Calculating unbiased tree-ring indices for the study of climatic and environmental change. The Holocene, 7(3), 361370. Retrieved from https://journals.sagepub.com/ doi/10.1177/095968369700700314

Cook, E.R., \& Kairiukstis, L.A. (1990). Methods of Dendrochronology. Applications in the Environmental Sciences. International Institute for Applied Systems Analysis. Dordrecht: Kluwer Academic Publishers, 394. http://dx.doi.org/10.1007/978-94-015-7879-0

Dai, A.G. (2011). Drought under global warming: A review. Wiley Interdisciplinary Reviews Climate Change, 2, 45-65. https://doi.org/10.1002/wcc.81

Didukh, Y. (2009). Ecological aspects of the global climate changes: reasons, consequences and actions. Bulletin of the National Academy of Sciences of Ukraine, 2, 34-44. Retrieved from http://nbuv.gov. ua/UJRN/vnanu_2009_2_12

Elferts, D. (2007). Scots pine pointer-years in northwestern Latvia and their relationship with climatic factors. Acta University Latvia, 723, 163-170. Retrieved from http://eeb.lu.lv/EEB/2007/Elferts.shtml

Finley K., \& Zhang, Ji. (2019). Climate effect on ponderosa pine radial growth varies with tree density and shrub removal. Forests, 10(6), 477. Retrieved from https://www.mdpi.com/1999-4907/10/6/477

Fritts, H.C. (1976). Tree rings and climate. London, New York and San Francisco: Academic Press. https://doi.org/10.1177/030913338000400214

Génova, M. (2012). Extreme pointer years in treering records of Central Spain as evidence of climatic events and the eruption of the Huaynaputina Volcano (Peru, 1600 AD), Climate Past, 8, 751-764. https:// doi.org/10.5194/cp-8-751-2012

Gleason, K.E., Bradford, J.B., Bottero, A., D’Amato, A.W., Fraver, S., Palik, B. J., ... Kern, C.C. (2017). Competition amplifies drought stress in forests across broad climatic and compositional gradients. Ecosphere, 8(7), 1-16. Retrieved from https://www.fs.fed.us/nrs/pubs/jrnl/2017/nrs_2017_ gleason_001.pdf

Gritsan, Y..I., Lovynska, V.M., Sytnyk, S.A., \& Hetmanchuk, A. I. (2019). Dendroindication of ecocli- 
matic condition in forest remediation area within Northern Steppe of Ukraine. Regulator y Mechanisms in Biosystems, 10(4), 457-463. Retrieved from https://medicine.dp.ua/index.php/med/article/ view/567

Holmes, R.J. (1994). Dendrochronology Program Library. Users Manual. University of Arizona, Tucson Retrieved from https://www.ltrr.arizona.edu/pub/ dpl-mac/68k/dpl.txt

Koval, I. (2013). Climatic signal in earlywood, latewood and total ring width of Crimean pine (Pinus nigra Pallasiana) from Crimean Mountains, Ukraine. Baltic Forestry, 19 (2), 245-251. Retrieved from https://www.balticforestry.mi.lt/bf/index.php? option $=$ com content $\&$ view $=$ article $\&$ id $=341 \&$ catid $=$ $42 \&$ Itemid $=\overline{1} 01$

Linderholm, H., Solberg, B., \& Lindholm, M. (2003). Tree-ring records from central Fennoscandia: the relationship between tree growth and climate along a west-east transect. The Holocene, 13(6), 887-895. https://doi.org/10.1191/0959683603hl671rp

Lindsey, R., \& Dahlman, L. (2019). Climate Change: Global Temperature. Retrieved from: https://www. climate.gov/news-features/understanding-climate/ climate-change-global-temperature

Marquardt, P.E., Brian, R., Miranda, B.R., Jennings, Sh., Thurston, G., \& Telewsk, F.W. (2019). Variable climate response differentiates the growth of Sky Island Ponderosa Pines. Trees, 33, 317-332. Retrieved from https://www.fs.fed.us/nrs/pubs/ jrnl/2018/nrs 2018 marquardt 001.pdf

McDowell, N., Pockman, W.T., Allen, C.D., Breshears, D. D., Cobb, N., Kolb, T., \& Enrico, A. (2008). Mechanisms of plant survival and mortality during drought: Why do some plants survive while others succumb to drought? New Phytol, 178, 719-739. https://doi.org/10.1111/j.1469-8137.2008.02436.x

Meshkova, V.L., \& Bajdyk, G.V. (2017). Perspective issues of research on forest entomology (in the wake of IUFRO congress to its 125th anniversary). The Bulletin of Kharkiv National Agrarian University. Series "Phytopathology and Entomology», 1-2. Retrieved from https://knau.kharkov.ua/uploads/ visn_ento_fito/2017/17.pdf

Natalini, F., Correia, A. C., Vázquez-Piqué J., \& Alejano R. (2015).Tree rings reflect growth adjustments and enhanced synchrony among sites in Iberian stone pine (Pinus pinea L.) under climatechange. Annals of Forest Science, 72, 1023-1033. Retrieved from https://link.springer.com/article/10.1007/s13595015-0521-6

Nolan, R.H., Drew, D.M., O'Grady, A.P., Pinkard, E.A., Paul, K., Roxburgh, S.H., ... Ramp, D. (2018). Safeguarding reforestation efforts against changes in climate and disturbance regimes. Forest Ecology and Management, 424, 458-467. Retrieved from https://www.sciencedirect.com/science/article/ abs/pii/S0378112718304146

Olivar J., Rathgeber, C., \& Bravot, F. (2015). Climate change, tree-ring width and wood density of pines in Mediterranean environments - Climate, radial growth, and wood International Association of Wood Anatomists. IAWA Journal, 36(3), 257-269. https:// doi.org/10.1163/22941932-20150098

Vitas, A. (2004). Dendroclimatological research of Scots pine (Pinus sylvestris L.) in the Baltic coastal zone of Lithuania. Baltic Forestry, 10(1), 65-71. Retrieved from https://www.balticforestry.mi.lt/bf/ PDF_Articles/2004-10[1]/65_71\%20Adomas\%20 Vitas.pdf

Wigley, T. M. L., Briffa, K. R., \& Jones, P. D. (1984). On the average value of correlated time series, with applications in dendroclimatology and hydrometeorology. Journal of Climatology and Applied Meteorology, 23(2), 201-213. Retrieved from https:// www.jstor.org/stable/26181323?seq=1

\section{Climatic signal in the regional tree-ring chronology of Pinus sylvestris L. in the Left-Bank Forest-Steppe}

\author{
I. Koval ${ }^{1}$
}

Knowledge of stands response to past environmental conditions can help predict how forests may respond to future climates. The climate influence on the radial growth of Pinus sylvestris L. in the stands of the LeftBank Forest-Steppe, which grow which grow the weak sod-podzolic soils has been studied. Standard dendrochronological methods are used. A regional tree-ring chronology of Scots pine has been created, which consists of 80 individual tree-ring series and is based on 6 local tree-ring chronologies, which contain 5424 layers of annual wood. Based on this series, the RESIDUAL index series was developed, from which the age trend was removed, which made it suitable for further in-depth dendroclimatic analysis. The reference years of minimal growth $(1936,1942,1954,1975,1979$, 2000, 2005, 2009 and 2012) were revealed, during which the width of the annual wood layers was lower than the corresponding values of the previous year by $20-46 \%$. Radial growth during these years was limited by precipitation, high temperatures of the growing season, extreme winter and early spring temperatures. The years of maximum growth $(1935,1943,1953$, 1988, 2004, 2011 and 2014) were characterized by a favorable ratio of temperature and moisture. Until 1979 during the minimum pointer years, radial growth was limited mainly by low temperatures and droughts, but after 1979 - only droughts and warm winters. Using the RESPONSE program with correlation and regression analyzes between the radial tree growth of Scots pine and climatic factors revealed that in the

Iryna Koval - Corresponding Member of the Forestry Academy of Sciences of Ukraine, Ph.D. in Agricultural Sciences, senior researcher of Laboratory of Forest Ecology. Ukrainian Research Institute of Forestry and Forest Melioration after G. M. Vysotsky, 86, Pushkinska str., Kharkiv, 61024, Ukraine. Tel.: +38-057707-80-01, +38-063-28-21-995. E-mail: Koval_Iryna@ukr.net ORCID: https://orcid.org/0000-0001-6328-1418 
second period (1989-2017) compared to the first (19601988) the negative impact of temperatures and the positive impact of precipitation during April-August on the radial growth. In the first period, the positive effect of precipitation during the growing season lasted a shorter period - only June-July. In the second period, the temperatures of June-December of the previous year had a stronger effect on the radial growth of the current year in contrast to precipitation, the impact of which, on the contrary, decreased.

Thus, the radial tree growth of Scots pine developed for the Forest-Steppe is suitable for further dendroclimatic analysis. The pointer years of minimal growth were revealed, which were characterized by a deficit of moisture during the growing season and extreme summer, winter and early spring temperatures. The years of maximum growth were characterized by a favorable ratio of heat and moisture.

A comparison of the response of radial growth of Scots pine to climate variation during 1960-1988 and 1989-2017 revealed an increase in the trees sensitivity to climate change. An increase in the significant correlations the radial tree growth of Scots pine and climatic factors in the second period compared to the first, indicating a weakening of pine stands and a possible some deterioration in radial growth in the coming years. However, given the plasticity of Scots pine and its adaptation to climate change at the present stage, we can recommend planting Scots pine in the stands of the Left Bank Forest-Steppe.

Key words: climate change; the radial tree growth of Scots pine; pointer years; sensitivity of trees; RESPONSE program; correlation and regression analyzes.

\section{Климатический сигнал в региональной древесно-кольцевой хронологии Pinus sylvestris L. для Левобережной Лесостепи}

\section{И.М. Коваль ${ }^{1}$}

Знание реакции древостоев на прошлые условия природной среды может помочь предсказать, как леса могут реагировать на будущий климат. Изучено влияние климата на радиальный рост Pinus sylvestris L. в насаждениях Левобережной Лесостепи, произрастающих на слабых дерновоподзолистых почвах. Использованы стандартные дендрохронологические методы. Была создана региональная хронология годичных колец сосны обыкновенной, которая состоит из 80 индивидуальных древесно-кольцевых серий годичных колец и

Коваль Ирина Михайловна - член-корреспондент Лесной академии наук Украины, кандидат сельскохозяйственных наук, старший научный сотрудник, ведущий сотрудник лаборатории экологии леса. Украинский научно-исследовательский институт лесного хозяйства и агролесомелиорации им. Г.Н. Высоцкого, ул. Пушкинская, 86, Харьков, 61024, Украина. Тел: +38-057-70780-45,+38-063-28-21-995. E-mail: Koval_Iryna@ukr.net ORCID: https://orcid.org/0000-0001-6328-1418 основана на шести местных хронологиях, содержащих 5424 слоя годовой древесины. На основе этого ряда построен ряд индекса RESIDUAL, из которого был удален возрастной тренд, что сделало его пригодным для дальнейшего углубленного дендроклиматического анализа. Выявлены опорные годы минимального прироста (1936, 1942, 1954, 1975, 1979 , 2000, 2005, 2009 и 2012), в течение которых ширина годичных слоев древесины была ниже соответствующих значений предыдущего года на 20-46\%. Радиальный прирост в эти годы был ограничен осадками, высокими температурами вегетационного периода, экстремальными зимними и ранними весенними температурами. Годы максимального прироста $(1935,1943,1953,1988,2004,2011$ и 2014) характеризовались благоприятным соотношением температуры и влажности. До 1979 г., в годы минимальных реперных лет, радиальный прирост ограничивался, в основном, низкими температурами и засухой, а после 1979 г. - только засухой и теплой зимой. С помощью программы RESPONSE с использованием корреляционного и регрессионного анализов между радиальным приростом сосны и климатическими факторами установлено, что во втором периоде (1989-2017 гг.), по сравнению с первым (1960-1988 гг.), было отрицательное влияние температур и положительное влияние осадков в течение апреля-августа на радиальный прирост. В первом периоде положительный эффект осадков на протяжении вегетационного периода длился более короткий период - только июнь-июль. Во втором периоде температуры июня-декабря прошлого года сильнее повлияли на радиальный рост текущего года в отличие от осадков, влияние которых, наоборот, уменьшилось.

Региональная древесно-кольцевая хронология сосны, созданная для Левобережной Лесостепи, пригодна для дальнейшего дендроклиматического анализа. Выявлены реперные годы минимального роста, которые характеризовались дефицитом влаги в вегетационный период и экстремальными летними, зимними и ранневесенними температурами. Годы максимального прироста характеризовались благоприятным соотношением тепла и влаги. При сравнении реакции радиального роста сосны обыкновенной на изменение климата в период 1960-1988 и 1989-2017 гг. установлено повышение чувствительности деревьев к изменению климата. Это проявилось в увеличении значимых связей между радиальным приростом сосны и климатическими факторами во втором периоде по сравнению с первым, что свидетельствует об ослаблении насаждений и о возможном некотором ухудшении радиального прироста в ближайшие годы. Однако, учитывая пластичность сосны и ее адаптацию к изменениям климата на нынешнем этапе, можем рекомендовать ее использование в древостоях Левобережной Лесостепи.

Ключевые слова: изменение климата; радиальный прирост сосны обыкновенной; реперные годы; чувствительность деревьев; программа RESPONSE; корреляционный и регрессионный анализы. 